Research article

\title{
A new species from Turkey: Eleocharis divaricata (Cyperaceae) and a note for E. atropurpurea
}

\author{
Mustafa Keskin ${ }^{1}$ (D), David Merrick² ${ }^{2}$
}

${ }^{1}$ Marmara University, Institute of Pure and Applied Sciences, Biology Program, 34722, Goztepe, Istanbul, Turkey

${ }^{2}$ Durham University, Department of Mathematical Sciences, Durham, DH1 3LE, United Kingdom

\begin{abstract}
In this study, a new species, Eleocharis divaricata, is introduced to science. It is easily separated from other species by its short and divaricate stems, blackish-purple achenes, and amphicarpic proliferation. Also, the presence of E. atropurpurea in Turkey is discussed. Finally, a new identification key is proposed for all Eleocharis species in Turkey.
\end{abstract}

Keywords: Eleocharis atropurpurea; E. divaricata; new species; sedge family; Turkey

\section{Introduction}

The sedge family, or Cyperaceae, is the third-largest monocot family, consisting of an estimated 5.000 species in 104 genera. The largest genera with approximate numbers of species are Carex, 2000 sp., Cyperus, 550 sp. and Eleocharis, $200 \mathrm{sp}$. (Goetghebeur, 1998; Simpson and Inglis, 2001).

The genus Eleocharis is characterized by the leafless stem, achene type, and toothed perianth bristles.

Almost all species of Eleocharis are quite similar to the untrained eye. Further, their natural habitats are similar, with a preference for creekside, swampy, semi-marshy areas, or ponds.

In Turkey, the genus is represented by seven species $(E$. quinqueflora (Hartmann) O. Schwarz, E. acicularis (L.) Roemer \& Schultes, E. atropurpurea (Retz.) C. Presl, E. palustris (L.) Roemer \& Schultes, E. mitracarpa Steudel, E. uniglumis (Link) Schultes and E. carniolica W.D.J. Koch) according to Flora of Turkey (Tan, 1985).

\section{Materials and methods}

On a social networking site an interesting specimen was shared as E. atropurpurea with detailed photographs by the second author who is a citizen scholar, but this identification was doubted by the first author who is authoring the genus Eleocharis for Turkey's Flora.

Later, samples were collected and subjected to scientific examination, leading to a conclusion that, they are not $E$. atropurpurea, and they belong to a new species close to $E$. atropurpurea (Retz.) C. Presl, and E. geniculata (L.) Roem. \& Schult.

\section{Results}

\subsection{The genus Eleocharis in Turkey}

\subsubsection{A new species for science from Turkey}

Eleocharis divaricata M.Keskin sp. nov. (Fig. 1).

Holotype: Turkey, Antalya: Konyaaltı, Boğa çayı vicinity, 4.xii.2020, D.Merrick (Holo NGBB)

Diagnose: It is related to E. atropurpurea (Retz.) C. Presl and E. geniculata (L.) Roem. \& Schult. It is easily separated from them by its achenes having a greenish stylopodium, amphi-

\footnotetext{
* Corresponding author.

E-mail address: trifolium@hotmail.com (M. Keskin).

https://doi.org/10.51753/flsrt.843057 Author contributions

Received 18 December 2020; Accepted 24 January 2021

Available online 1 February 2021

(C) 2021 Dergipark. All rights reserved.
} 
Table

A comparison of E. atropurpurea, E. geniculata and E. divaricata $(* * *=$ not any knowledge)

\begin{tabular}{|c|c|c|c|c|c|}
\hline & \multicolumn{2}{|c|}{ E. atropurpurea } & \multicolumn{2}{|c|}{ E. geniculata } & \multirow{2}{*}{$\frac{\text { E. divaricata }}{\text { in this study }}$} \\
\hline & Blake, 1939 & Svenson, 1929 & Cosewic, 2009 & Menapace, 2020 & \\
\hline Stem & $\begin{array}{l}\text { filiform, at most } 0.3 \mathrm{~mm} \\
\text { wide }\end{array}$ & filiform, strict or bent & $\begin{array}{c}\text { thin or filiform, c. } 1 \mathrm{~mm} \\
\text { at base; } 0.5-0.6 \mathrm{~mm} \text { wide } \\
\text { at the tip }\end{array}$ & $0.2-1 \mathrm{~mm}$ & $\begin{array}{c}\text { thin or filiform, } \\
\text { caespitose, } \mathrm{c} .1 \mathrm{~mm} \text { at } \\
\text { base; } 0.5-0.6 \mathrm{~mm} \text { wide at } \\
\text { tip; amphicarpic } \\
\text { proliferation }\end{array}$ \\
\hline Glumes & $1-1.3 \mathrm{~mm}$ & $* * *$ & $1.5-2 \mathrm{~mm}$ & $0.8-3 \mathrm{~mm}$, ovate to elliptic & $1.7-2.0 \mathrm{~mm}$ \\
\hline Stamen & 1 & $1-3$ & $* * *$ & $* * *$ & \\
\hline Achenes & $0.6-0.65$ & $0.5 \mathrm{~mm}$ & $0.7-1.1 \mathrm{~mm}$ & $\begin{array}{c}\text { brown ripening to black, } \\
\text { biconvex, orbicular to } \\
\text { obpyriform, } 0.5-1.1\end{array}$ & $\begin{array}{l}1 \mathrm{~mm} \text {, blackish purple, } \\
\text { stipitate, orbicular to } \\
\text { obpyriform }\end{array}$ \\
\hline Stylopodium & $\begin{array}{l}\text { very short, depressed, } \\
\text { white }\end{array}$ & $\begin{array}{l}\text { markedly flattened, or } \\
\text { absent }\end{array}$ & $\begin{array}{l}\text { with a flat and fairly } \\
\text { wide tubercle, green }\end{array}$ & $\begin{array}{l}\text { stramineous to whitish, } \\
\text { umbonate to subconic, } 0.2- \\
0.4 \times 0.2-0.5 \mathrm{~mm} \text {, apex } \\
\text { rounded to acute }\end{array}$ & $\begin{array}{l}\text { deltoid narrow than wide } \\
\text { of achenes, usually light } \\
\text { green }\end{array}$ \\
\hline Bristles & $\begin{array}{l}\text { 4-6, thin, white, } \\
\text { transparent, shortly } \\
\text { spinose or smooth; } \\
\text { shorter than achenes or } \\
\text { sometimes absent; } \\
\text { shorter than achenes or } \\
\text { equal }\end{array}$ & $\begin{array}{l}\text { thin, transparent, usually } \\
\text { stubby or wanting; } \\
\text { shorter than achenes or } \\
\text { equal }\end{array}$ & $\begin{array}{l}\text { thin, purplish-brown, } \\
\text { equal to achenes }\end{array}$ & $\begin{array}{l}\text { (0-)4-8, typically } 7, \text { red- } \\
\text { brown, rarely whitish, } \\
\text { vestigial to much- } \\
\text { exceeding tubercle, } \\
\text { typically equaling achene, }\end{array}$ & $\begin{array}{c}\text { (6-)7, white, spinose at } \\
\text { upper parts or } \\
\text { completely, longer than } \\
\text { achenes }\end{array}$ \\
\hline
\end{tabular}

carpic proliferation, long and wide glumes, and white perianth bristles longer than the achenes (Table).

Description: Plants annual or short-lived perennial with amphicarpic proliferation. Stems $7-10 \mathrm{~cm}$, thin or filiform, caespitose, c. $1 \mathrm{~mm}$ at base, $0.5-0.6 \mathrm{~mm}$ wide at the tip, shiny dark green.

Leaf sheaths 1 or 2 , reddish or mauve, obliquely truncate. Inflorescences 4-8 mm ovate-deltoid, obtuse at apex; manyflowered; flowers densely imbricate.

Lower glumes 2, equal and sterile, large green carina on the back, 3-nerved and longer than others, each glume covering up to half the spikelets. Glumes 1.7-2.0 x 1.1-1.3 mm, median nerve green and carinate, brown outward toward the edge, outer parts transparent, membranous, obscurely veined.

Stamens 2; filaments longer than achenes and bristles, anthers 0.8-1.1 mm. Stigma 2, hairy. Perianth bristles (6-)7, white, spinose on the upper parts or completely, longer than achenes.

Achenes obpyriform; thickly bordered at the edge, $1 \mathrm{~mm}$ long, widest at the middle, striate, blackish-purple, stipitate at the base; stylopodium deltoid narrower than the achene, usually light green or sometimes whitish.

\subsection{A note on the presence of E. atropurpurea in Turkey}

E. atropurpurea is known from a single gathering in Turkey (Tan, 1985).:

Muğla: Köyceğiz, Dalyan, Sülüngür Lake, Uotila 30598!

The species, widespread in the tropics and subtropics, is introduced in Europe, and the specimen in Edinburgh Herbarium was investigated by the first author.

Consequentially, the single specimen from Turkey is certainly not $E$. atropurpurea due to its general structure being long-rhizomatous, perennial, long and thick-stemmed, and the achenes not being black.

It is equal to abnormal form of E. palustris (L.) Roemer \& Schultes with small inflorescence that is the one that is very common in Turkey. For this reason, E. atropurpurea has been removed from the list of Turkey's Flora (Fig. 2.).

\subsection{A new identification key}

1. Achenes blackish-purple

E. divaricata

1. Achenes usually brownish

2. Stylopodium absent

E. quinqueflora

2. Stylopodium present

3. Achenes tri-faced with longitudinal and transverse veins

E. acicularis

3. Achenes two-faced, never longitudinally and transversely veined

4. Stylopodium as broad as achenes, always broader than long

E. mitracarpa

4. Stylopodium at most as wide as, but usually narrower than, the achenes

5. Bristles 6-8 and longer than achenes

E. carniolica

5. Bristles usually 4-6 and at most equal to the achenes

6. Lowest glume of spikelet sterile, encircling the spikelet base; achenes minutely tuberculate-striate or smooth

E. uniglumis

6. Lowest two glumes sterile, each halfencircling the spikelet base; achenes usually smooth

E. palustris

\section{Discussion}

While seven Eleocharis species were reported in Flora of Turkey (Tan, 1985), E. atropurpurea was removed from the list 
for being misidentified and not actually being present in Turkey.

An interesting specimen of Eleocharis was collected from Antalya. It is understood that this collected plant differentiates from all other species of Eleocharis by its blackish-purple achenes, long bristles, amphicarpic proliferation, long and wide glumes. For this reason, this specimen is introduced to the scientific world as E. divaricata. A new key for Turkish Eleocharis has been prepared to identify species in Turkey.

Acknowledgments: The first author would like to thank the ANG foundation for their financial contribution to the Edinburgh trip.

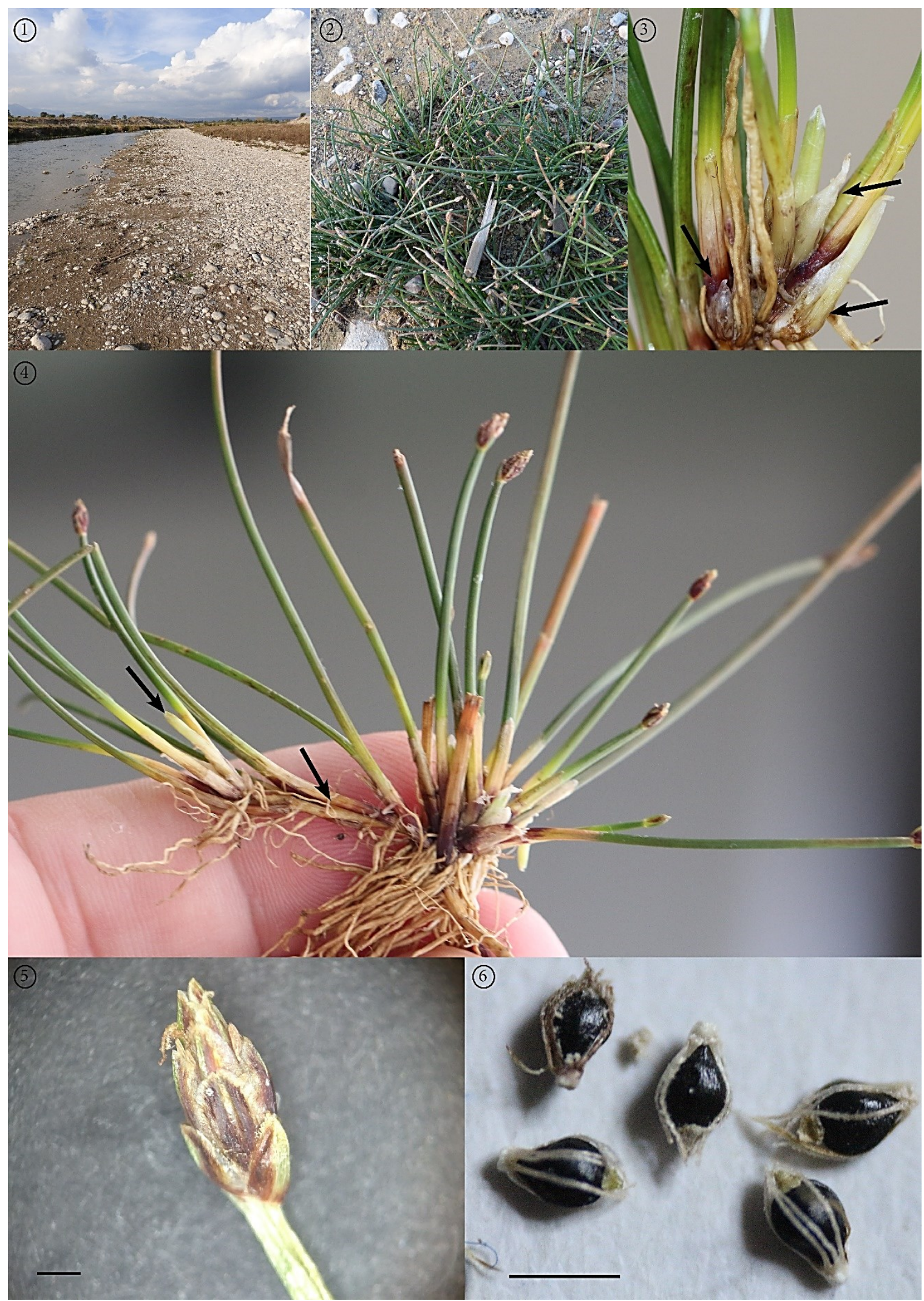

Fig. 1. Eleocharis divaricata M.Keskin sp.nov. (1) Habitus, (2) General view, (3) Close up from the base, (4) A single plant, (5) A spikelet, (6) Achenes. (The arrow indicates amphicarpic shoots, all scale bars $1 \mathrm{~mm}$ ). 


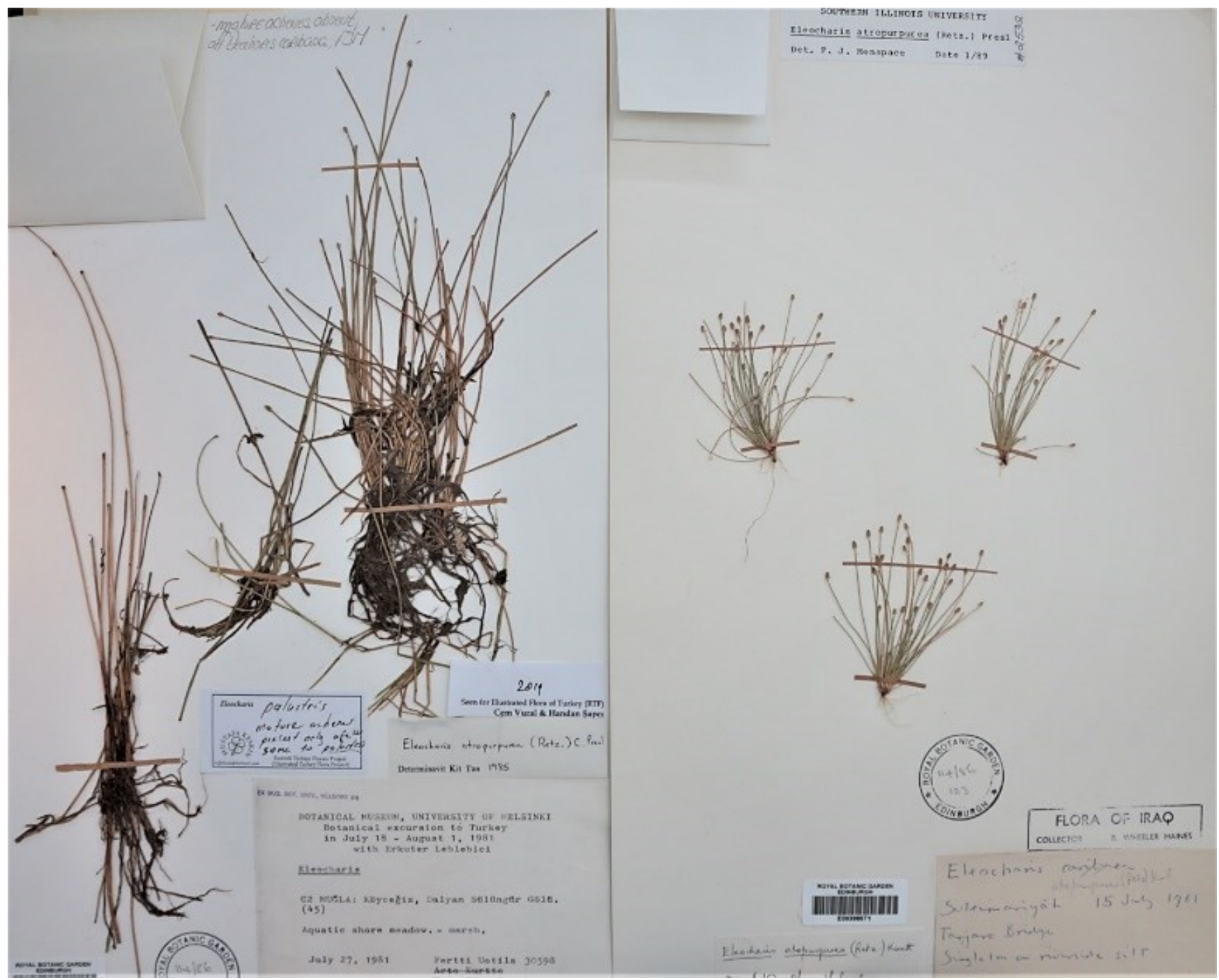

Fig. 2. A visual comparison for (left) the E. palustris identified as E. atropurpurea in Flora of Turkey, Uotila 30598 and (right) real E. atropurpurea.

Conflict of interest: The authors declare that they have no conflict of interests.

\section{References}

Blake, S. T. (1939). A monograph of the genus Eleocharis in Australia and New Zealand. The Proceedings of the Royal Society of Queensland, 1(12), 88-132.

Cosewic, (2009). COSEWIC assessment and status report on the Bent Spike-rush Eleocharis geniculata, Great Lakes Plains population, and Southern Mountain population, in Canada. Committee on the Status of Endangered Wildlife in Canada. Ottawa. vii +30 pp. (www.sararegistry.gc.ca/status/status_e.cfm).

Goetghebeur, P. (1998). Cyperaceae. In: Kubitzki K. (ed) The families and genera of vascular plants IV (pp. 141-190). Springer-Verlag, Berlin.

Menapace, F. J. (2020). Eleocharis R.Br. In: Flora of North America Edito-
Informed consent: This manuscript did not involve human or animal participants; therefore informed consent was not collected.

rial Committee, eds. 1993+. Flora of North America North of Mexico. New York and Oxford. vol. 23: 101. http://beta.floranorthamerica.org/ Eleocharis geniculata. Last accessed on December 17, 2020.

Simpson, D. A., \& Inglis, C. A. (2001). Cyperaceae of economic, ethnobotanical, and horticultural importance: a checklist. Kew Bulletin $56,257-360$.

Svenson, H. K. (1929). Monographic studies in the genus Eleocharis. Rhodora, 31, 224-242.

Tan, K. (1985). Eleocharis R.Br. In: Davis, P. H. (ed) Flora of Turkey and The East Aegean Islands vol.9 (pp. 48-53). Edinburgh at the University Press.

Cite as: Keskin, M., \& Merrick, D. (2021). A new species from Turkey: Eleocharis divaricata (Cyperaceae) and a note for E. atropurpurea. Front Life Sci $R T, 2(1), 10-13$. 